\title{
Organizational Commitment and its Relationship to Perceived Leadership Style in an Islamic School in a Large Urban Centre in Canada: Teachers' Perspectives
}

\author{
Mohamed Fathy Hussein \\ Al-Azhar University, Egypt \\ drmeducation@yahoo.com \\ José L. da Costa \\ University of Alberta, Canada \\ Jose.da.Costa@ualberta.ca
}

\begin{abstract}
Drawing on a theoretical orientation based on the moral perspective which maintains that the relationship between the leader and the followers is not one of power, but of sharing mutual needs, aspirations and values. This empirical mixed-method study focused on understanding the professional lives of teachers, particularly their organizational commitment in relation to the principal's leadership style, in an Islamic School located in a large urban centre in Canada. Data were gathered using (a) individual semi-structured interviews with teachers and the principal of the school, (b) adaptations of Bass and Avolio's Multifactor Leadership Questionnaire (1996), and (c) an adaptation of Meyer and Smith's Organizational Commitment Questionnaire (1993). The findings from this study suggest a high level of teachers' overall organizational commitment existed in the study site. Furthermore, it appears that it is more appropriate to consider the affective, continuance and normative manifestations of organizational commitment as components rather than types of organizational commitment.
\end{abstract}

\section{Introduction}

Organizational commitment has been identified as a predictor of behaviour within organizations. In educational organizations where teachers are considered to be the most fundamental stakeholders after students, it is stated that teachers' commitment has been identified as a key facet of a school's capacity for reform and renewal (Geisjel et al., 2002 , p. 232). Factors such as tardiness, absenteeism and turnover are also identified as manifestations of commitment (e.g., Geurts, 1999; Burton, Lee, \& Holton, 2002). The literature, as well, attributes much responsibility to school principals and their leadership styles given their very substantial impact on the whole school operation and, in particular, teachers' commitment to the organization.

In fact, regardless of the type of organization (e.g., government agencies, institutions or small enterprises), the central and most effective factor required to enhance human resources is leadership (Bennis \& Nanus, 2003, p. 8). Leaders are those most able and capable of creating and maintaining cultures where people feel valued, where they are energized and creative, and where they love coming to work (Bennis \& Townsend,

Journal of Contemporary Issues in Education, 2008, 3(1), pp. 17-38.

ISSN 1718-4770 C 2008 University of Alberta

http://ejournals.library.ualberta.ca/index.php/JCIE 
2005, p. 7). In education, all the literature refers directly or indirectly to the importance of school leaders and their crucial role, at some or all levels of the educational structure, in promoting motivation, performance, and commitment of employees (Katerynych, 1994, p. 3). Technically, everything school leaders do could be regarded in one way or another as bringing support for teaching and learning (Prestine \& Nelson, 2005, p. 47). For this reason, educators and policymakers alike seek a frame for effective leadership that can produce sustainable school improvement (Lambert, 2002, p. 38) and continuous teacher commitment. Thus, school principals should be aware of their critical and most influential status in the educational system.

While many teachers leave school and teaching because of factors remote from the school administrators' control, there are still many who cite poor and inefficient leadership and the absence of administrative support as reasons for leaving (Fiore, 2004, p. 135). On the other hand, many teachers suggest that their commitment to school is linked to their commitment to administrators and they feel more committed to principals who are able to create work communities that are supportive and stimulating, studentoriented, facilitate feelings of community, and foster their feelings of efficacy (Joffres, 1998, p. 170).

\section{Theoretical Background and Literature Review}

This review focuses on contributions concerning the two main dimensions of this research: (a) teachers' sense of organizational commitment and (b) principal leadership style.

\section{Teachers' Organizational Commitment}

Organizational commitment has attracted considerable attention in theory and research. The literature is replete with a variety of definitions and explanations for it. This may be because, as Yoon and Thye (2002) declare, it is a broad-ranging concept that goes across many organizational and sociological domains (p. 97). Nevertheless, the variety of definitions for organizational commitment with all its different measures shares a common notion that organizational commitment is a bond of the individual to his or her organization (Camilleri, 2006, p. 64). After studying organizational commitment, Meyer and colleagues (e.g., Meyer \& Allen, 1991; Jaros, 1997; Meyer \& Smith, 2000; Meyer \& Heroscvitch, 2001; Powell \& Meyer, 2004), argue it consists of three integrated but distinct components. These components are: (a) affective commitment which reflects the member's emotional attachment to, identification with, and involvement in the organization; (b) normative commitment which reflects the member's sense of obligation to the organization and his or her willingness to exert extra effort on behalf of it; and (c) continuance commitment, one's desire to maintain membership in the organization, based upon the member's perception of the costs that are associated with leaving it.

In a study conducted with public and private sectors employees, Zeffane (1994) found managerial activities to have significant impact on various aspects of employee commitment. Also, a study by Meyer et al. (2002) demonstrated that perceived organizational support has the strongest positive correlation with affective commitment (p. 83); the results also indicated that correlations involving work experience variables were generally much stronger than those involving personal characteristics (p. 32). In 
another study, Coladarci (1992) found that the principal's conduct is a significant but modest predictor of teachers' commitment to teaching. It appears from previous research that a relationship could exist between the principals' leadership styles and the components of teachers' organizational commitment.

\section{Principal Leadership Styles}

The term 'principal' was first noted in the minutes of a meeting for the board of Education of Albany, New York in May 1886 (Shen, 2005, p. 2). Also, the conception of leadership, when it was mentioned, was often seen as a subset of management; there were no equivalent collection of leadership skills and tasks; rather the manifestation of it was restrained by a framework of management competences (Early, 2003, p. 353). Numerous attempts have been made to make sense of the various roles and responsibilities of the modern principalship and the dependent relationship between leadership and management (Phillips, Raham, \& Renihan 2003, p. 16). While an in-depth treatment of this topic is beyond the scope of this study, it is not difficult to observe various contributions highlighted by many remarks distinguishing between the two concepts concepts. For instance, the distinction that leaders are people who do the right things while managers are people who do things right, in other words, the former are concerned about vision, goals, intentions, purpose, and effectiveness whereas the latter are very concerned about efficiency and the short-term operations (Bennis \& Townsend, 2005, p. $6)$.

Broadly speaking, management and leadership perspectives are not fixed entities, they evolve and develop because of continuous research, although the range of the change may vary from one context to another. In the field of education, Bush (2003) asserts that management and leadership are subject to rapid and complex change. This is partially because they are still developing and new theories and perspectives are changing assumptions and expectations. In addition, the academic field itself necessarily reflects leadership and management practices which are powerfully affected by other imperatives (p. 347). Leadership theory evolved in this direction over the course of time. It moved from charismatic leadership and traits theory (Kanungo \& Conger, 1992; House \& Aditya, 1997; Steyrer, 1998; Turner, 2003; Ladkin, 2006) to more extensive and holistic perspectives taking into consideration leadership behaviour and organizational processes as well as interactions between the leader and subordinates. Understanding these perspectives and theories will help to:

1. Assess personal strengths and weaknesses related to skills necessary for effective leadership;

2. Realize the importance of moral purpose and ethical values for leadership; and,

3. Use power appropriately in order to positively influence and gain commitment from others (Chance \& Chance, 2002, p. 85-86).

A currently prominent conceptualization of leadership is transformational theory. It has been the subject of systematic research in non-educational organizations for several decades (Marks, \& Printy, 2003, p. 375). Transformational theory is an outgrowth of 
earlier transactional theory which viewed leadership as being primarily designed around transactions between the leader and the followers, namely those who would give their effort and commitment as an exchange for something in return (Reinhartz, \& Beach, 2004, pp. 35-36). According to transactional theory, teachers' commitment depends upon resources received from the school and appreciated by teachers.

Transformational theory, on the other hand, is primarily studied in terms of the leader's effect on his or her subordinates and the behaviour used to accomplish this effect (Yukl, 1999). It refers, as Bass (1999) mentions, to the leader moving the followers beyond their immediate self-interests through idealized influence, inspirational motivation, intellectual stimulation or individualized consideration (Bass, 1999). According to Bass and Steidlmeier (1999) “...the literature on transformational leadership is linked to the long-standing literature on virtue and moral character, as exemplified by Socratic and Confucian typologies" (p. 11). Thus, a transformative principal, as Blase and Blase (2003) declare, can positively influence all major aspects of teachers' work including the:

1. Affective dimension: teachers' satisfaction, motivation, esteem, security, and sense of inclusion;

2. Classroom dimension: teachers' reflection, innovation, creativity, and professional growth; and,

3. School wide dimension: teachers' experience, commitment, and school efficacy (p. 5).

Based on this perspective, many researchers have tried to investigate various aspects of leadership style and its role on the effectiveness of organizational life.

A study by Jung and Sosik (2002) demonstrated that transformational leadership is positively related to group empowerment, cohesiveness, and effectiveness. Also, Bogler (2001) found that principals' leadership style affects teachers' satisfaction, both directly and indirectly, through their occupational perception. This supports the findings of Foels, Driskell, Mullen, and Salas (2000) that group members experiencing democratic leadership were more satisfied than group members experiencing autocratic leadership. However, group member satisfaction was moderated by variables such as gender, composition of the group, and its size. Another study by Yu, Leithwood, and Jantzi, (2002) has indicated that there is a weak but significant effect of transformational leadership on teachers' commitment to change and reform. This work reinforces the findings of a study by Geijsel, Sleegers, Leithwood, and Jantzi (2003) which demonstrated an effect of transformational leadership on teachers' commitment to school reform.

\section{Theoretical Orientation}

We were guided in this study by a theoretical orientation based on the moral perspective which maintains that the relationship between the leader and the followers is not one of power but of sharing mutual needs, aspirations and values (Shen, 2005, p. 118). Values become the mental map guiding individuals' conduct and thoughts and serve as the foundation for these processes (Johansson, 2004, p. 623). School as an organizational 
structure is supposed to have an established set of values, norms, and expectations which guide behaviours and roles by those belonging to it (Chance \& Chance, 2002, p. 62). Educational leadership occurs within this frame of values which includes:

1. Principles of democracy, law, rules, regulations and policies;

2. Professional practices;

3. Ethical guidelines; and,

4. Personal convictions (Thomas \& Davis, 2000, p. 55).

For those who adhere to similar educational and moral values, the basic elements making this a good place to work are present, for they will have leaders who enounce what they know to be good. Members of such communities are expected to be empowered and committed as they will feel that they are backed by someone who thinks and feels the same way they do (Bottery, 2004, p. 208). On the contrary, many inconveniences, especially regarding teachers' commitment and behaviours, seem to arise from the possibility that teachers and principals have different values and conceptions of leadership. To further our understandings of leadership, this paper explores what teachers working in an Islamic school existing within a predominantly non-Islamic society identify as the characteristics of effective leaders. It also paves the way toward clarifying and understanding the conception of leadership as well as exploring its relation to teachers' sense of organizational commitment.

\section{Research Questions}

As different cultures, societies and communities interpret leadership in different ways, the need to explore these constructions becomes highly meaningful in multi-ethnic contexts (Shah, 2006, p. 366). This study focuses on understanding the professional lives of teachers in an Islamic School in a large urban centre in Canada and especially the levels of their organizational commitment in relation to the principal's leadership style. It gives insights into the school's internal life at a micro-political level. While the relationship between organizational commitment and leadership style in a highly valuebased organization is central to the conceptualization of this study, and the role of work experience as suggested by Meyers' et al. (2002) is useful, we were also very interested in exploring any gender differences that may exist among our own research participants. Consequently, our research questions focused on the following:

1. What are the levels of teachers' organizational commitment in the Islamic School?

2. Are there any differences in teachers' sense of organizational commitment regarding their gender and years of experience?

3. How do teachers in the Islamic School perceive their principal's leadership style?

4. What are the differences in teachers' perceptions of the principal's leadership style regarding their gender and years of experience? 
5. What is the relationship between the principal's leadership style as perceived by teachers in the Islamic School and their sense of organizational commitment?

\section{Method}

This study made use of a mixed method approach. While questionnaire data formed the foundation of the data collected for this research, we also gathered interview data with a smaller number of participants to enable us to better understand the questionnaire results. With reference to the method, descriptions of the research site, participants, measures, data analysis, limitations, and delimitations are provided below.

\section{The Research Site}

The research site was selected on the basis of its size, length of time in operation, homogeneity of the workforce, and its strong value-base. The school has been in operation for more than two decades and in 2007 had a student enrollment of between 600 and 800 students (actual numbers masked for confidentiality purposes) attending classes from kindergarten to grade 9. It was founded with the goal of developing the individual's learning and intellectual skills through an integration of Islamic curriculum and that prescribed by Alberta Education. The school provides to its students the standard academic curriculum as required by Alberta Education together with a full academic program encompassing Islamic and Arabic language studies. Hence, religious and second language studies are merged with the Alberta prescribed program of studies curriculum.

Given the fact that the school teaches students Islamic culture and provides them with Islamic religious education, it has taken care to provide an enhanced Islamic atmosphere throughout the entire day from when children arrive at school until they leave for home. For the purpose of insuring this, the teaching staff (there were between 30 and 45 teachers in the school) - almost 90 percent of whom were Muslim —were chosen and appointed carefully so as to pursue the school's mission. The teachers understood they should accept to follow the school's policies and Islamic traditions within the school building especially regarding the style of dress. The female teachers, even the nonMuslim ones, were veiled such that they were not recognized as non-Muslim unless they chose to declare so. The school principal had a part-time appointment and was nonMuslim; however, as a professional, this person was very aware of the Islamic code of conduct and traditions.

The school's workforce can be described in terms of its homogeneousness by what Schneider (1987) proposes as the attraction-selection-attrition (ASA) model. He assumes that individuals are attracted to, selected by, and stay with organizations to the extent that their personal characteristics are suited to the organization's design (i.e., culture, policies, and structure). Further, those having personal characteristics not suited to the organization are expected to be more inclined to withdraw even after gaining membership in the school. The consequent members' attributes resulting from this process define the nature of the organization and its dominant culture (Jones, 1998, pp. 869-870). 


\section{Participants}

All teachers from the Islamic School (a pseudonym) were invited to participate in this study. The invitation was made through an information letter (to which the survey questionnaire was attached) delivered to all the teachers in the school. Participants were asked to seal the completed questionnaires in envelops provided and to either deposit them in the mail box or deliver them by hand to the researcher. The completion of these questionnaires was entirely voluntary and responses were anonymous.

The final sample completing the questionnaire consisted of 23 teachers with a response rate of 66 percent. Of these, nine teachers (39 percent) had more than five years experience and fourteen (61 percent) had five or fewer years of experience. The majority of respondents, sixteen (70 percent), were female and a minority, seven (30 percent), were male.

As the questionnaire aimed only at providing a "snapshot" of the current state of teachers' perceptions of leadership style and their own level of commitment to their organization, semi-structured individual face-to-face audio-recorded interviews in Arabic and English languages with 12 teachers from the school were also conducted. The aim was to explore the reasons behind the teachers' perceptions of the principal's leadership style and behind their sense of organizational commitment. Of this group, some of the teachers were Muslim and others were non-Muslim, some were male and others were female. Twelve individual interviews, of 30 to 45 minutes each, were conducted with six teachers - each was interviewed two times.

\section{Measures}

The survey consisted of three sections. The first section contained an introductory letter and probed demographic information about the respondents. The second section consisted of Bass and Avolio's Multifactor Leadership Questionnaire (MLQ) (1996). The MLQ describes the principals' leadership style, as perceived by teachers, in terms of three main dimensions: transformational leadership, transactional leadership, and laissez faire (non-leadership) style. Transformational leadership is explored in terms of five subdivisions: (a) idealized attributes, (b) idealized behaviours, (c) inspirational motivation, (d) intellectual stimulation, and (e) individual consideration. Transactional leadership is subdivided into three sub-categories, namely: (a) contingent reward, (b) management-by-exception "passive," and (c) management-by-exception. Teachers were asked to rate their principal's school leadership behaviours on a 5-point Likert-type scale ranging from "not at all" (1) to "frequently, if not always" (5).

The third section consisted of the adapted version (adapted specifically to the school setting as the organization) of the Organizational Commitment Questionnaire (OCQ) by Meyer and Smith (1993). The OCQ has three subscales of six items each. These are the (a) affective commitment scale, (b) continuance commitment scale, and the (c) normative commitment scale. Teachers were asked to respond on a 5-point Likerttype scale ranging from "strongly disagree" (1) to "strongly agree" (5). 
Both the MLQ and OCQ are very well established and have been extensively used during the past two decades. However, we used the split-half reliability analysis to ensure that the measures, as used in our study, demonstrated reliability coefficients similar to those found by other researchers. Table 1 demonstrates the reliability coefficients for the MLQ. Because there were an odd number of items in the scales, the split produced an unequal number of items in each half, so the unequal-length Spearman-Brown reliability coefficients are reported. The values of the coefficients indicate that the MLQ scale has strong internal consistency.

Table 1. Spearman reliability coefficients for $M L Q$

\begin{tabular}{|l|c|}
\hline \multicolumn{1}{|c|}{ Variable } & Spearman coefficient \\
\hline Transformational leadership scale & 0.900 \\
\hline Transactional leadership scale & 0.861 \\
\hline Laissez faire (non-leadership) scale & 0.827 \\
\hline Multifactor Leadership Questionnaire & 0.863 \\
\hline
\end{tabular}

The OCQ split-half reliability coefficients were also calculated for each of its subscales using the Spearman-Brown formula; results are displayed in table 2. The analysis suggests strong internal consistency within each of the subscales measured by the Organizational Commitment Questionnaire.

Table 2. Spearman reliability coefficients for OCQ

\begin{tabular}{|l|c|}
\hline \multicolumn{1}{|c|}{ Variable } & Spearman coefficient \\
\hline Affective commitment scale & 0.892 \\
\hline Continuance commitment scale & 0.797 \\
\hline Normative commitment scale & 0.879 \\
\hline Organizational Commitment Questionnaire & 0.856 \\
\hline
\end{tabular}

\section{Data Analysis}

All questionnaire data collected were statistically analyzed using SPSS, version 13. Means and standard deviations were calculated. Group comparisons were conducted using simple t-tests (e.g., comparisons between participants' levels of organizational commitment in terms of their gender and years of experience). Also, backward stepwise regression analysis was utilized to explore the relationships between leadership style and various forms of organizational commitment. The anecdotal data collected from the interviews were analyzed thematically. Themes emerged both deductively and inductively.

\section{Limitations of the Study}

The nature of the study, given the purposive sampling approach, does not allow for generalization of the results. However, the results of it may be transferable to other contexts similar to the one reported in this study. The reader is cautioned that this study is context-bound because it was conducted in a school having special cultural and environmental dimensions. These cultural and environmental dimensions have their own 
impact and presence in the results of the study. Secondly, this study investigates organizational commitment perceived by teachers working in a school serving the cultural and religious needs of a minority to which most of them have some kind of "belongingness."

\section{Delimitations}

While we draw on many very interesting and contested notions related to leadership and commitment, we cannot explore all of these within the present study. The distinction between leaders and managers and what it means to be a school principal are not issues that we sought to resolve in this research. We also recognize that there are an almost infinite number of ways of conceptualizing leadership practices, many of which are not commensurate with this case. It was not our goal to provide clarity on these conceptualizations and debates.

\section{Findings and Discussion}

The study findings are arranged thematically so as to address the questions posed at the beginning of this paper. Firstly, the levels of teachers' commitment are presented according to their response on the OCQ and the data collected from the interviewees, then teachers' perceptions of the principal leadership style are depicted in details, and, lastly, the relationship between teachers' organizational commitment and the school principal's leadership style is explored.

\section{Levels of Teachers' Organizational Commitment}

Meyer and Allen argued that it is more appropriate to consider affective, continuance, and normative commitment to be components, rather than types, of organizational commitment as the employee's relationship with his or her organization can reflect varying degrees of all three (Meyer \& Allen, 1997, p. 13). The levels of teachers' organizational commitment are presented in table 3.

Table 3. Means and standard deviations for teachers' organizational commitment (OC) in the Islamic School

\begin{tabular}{|l|c|c|}
\hline \multicolumn{1}{|c|}{ Variable } & Mean & Std. deviation \\
\hline Affective & 20.70 & 5.49 \\
\hline Continuance & 22.87 & 3.52 \\
\hline Normative & 20.30 & 5.60 \\
\hline Overall commitment & 63.87 & 13.70 \\
\hline
\end{tabular}

OCQ results show that teachers tend to have a very high level of organizational commitment in the Islamic School with an overall score of 63.87 (range between 18 and 90). As can be seen in Table 1, teachers generally ranked the three components of organizational commitment (e.g., continuance commitment, affective commitment, and normative commitment) very highly (range from 6 to 30). Consistent with the above 
results, five teachers out of the six interviewed indicated that they felt very committed to their school.

These results indicate that teachers in the school believe that they are connected to their organization by feelings of obligation and duty and by virtue of this belief they feel teaching children Islamic culture and religion is the right and moral thing to do. This commitment is clearly illustrated in the words of a teacher respondent when he described his work in the school saying:

I feel that teaching here is a mission as I teach Muslim children in a non-Muslim society. As we are minority here I believe that children come to this school to acquire the Islamic knowledge and good manners, so my role as a Muslim is to help them with that.

It seems that he is culturally bound to the school and is aware of its mission, which is to pass the Islamic knowledge and culture to Muslim children living in Canadian society. One subtle characteristic of this school is that most of its members and community have Middle Eastern origins; they share the same religion and cultural homogeneity. They know that they are a minority within the Canadian society so this school was established to insure that their culture and Islamic knowledge be passed on to younger generations. The school's courtyard sometimes works as a social center for the Muslim community where they have their own meetings and celebrations. Another nonMuslim teacher articulated his organizational commitment saying:

I feel very committed to working at this school. I enjoy the atmosphere and the support I get from the administration, the parents, and the school community. I want to continue to work at this school because I love to teach and I am treated as a professional ... and given the opportunity to grow....

Such is not the case, however, for teachers whose essential link to school as an organization is not for reasons of emotional attachment but rather because of a recognition that the costs associated with doing otherwise are too high expensive (Meyer \& Allen, 1997, p. 24)

Differences in Teachers' Levels of Organizational Commitment with respect to Gender and Years of Experience

In the next step, differences in the levels of organizational commitment between male and female teachers are explored, followed by the differences according to teachers' years of experience. To explore the differences between teachers' levels of organizational commitment according to their gender, a t-test was computed. The results are presented in table 4 . 
Table 4. Differences in the levels of teachers' organizational commitment in the Islamic School according to gender

\begin{tabular}{|l|l|c|c|c|c|}
\hline \multicolumn{1}{|c|}{ Variable } & \multicolumn{1}{|c|}{ Teacher's gender } & mean & Std. Deviation & t-value & Sig. \\
\hline \multirow{2}{*}{ Affective } & male & 20.57 & 5.06 & -0.07 & 0.945 \\
\cline { 2 - 4 } & female & 20.75 & 5.83 & & \\
\hline \multirow{2}{*}{ Continuance } & male & 22.43 & 2.30 & -0.39 & 0.701 \\
\cline { 2 - 4 } & female & 23.06 & 3.99 & & \\
\hline \multirow{2}{*}{ Normative } & male & 20.86 & 5.08 & 0.31 & 0.762 \\
\cline { 2 - 4 } & female & 20.06 & 5.96 & & \\
\hline \multirow{2}{*}{$\begin{array}{l}\text { Overall } \\
\text { commitment }\end{array}$} & male & 63.86 & 10.14 & -0.00 & 0.998 \\
\cline { 2 - 4 } & female & 63.88 & 15.30 & & \\
\hline
\end{tabular}

$\begin{array}{lll}\mathrm{df}=21 & \text { n. }(\text { male })=7 & \text { n. }(\text { female })=16\end{array}$

It seems from these results that there are no significant differences in the levels of organizational commitment between male and female teachers. They both have almost the same organizational commitment. This is inconsistent with the findings of a study by Reyes (1992) who found that female teachers tend to have higher school commitment than male teachers. This finding could be due to the small sample size in the present study, or it could be congruent with the results of Kacmar, Carlson and Brymer (1999) who found that gender is not good predictor of any of the forms of organizational commitment.

To explore organizational commitment differences between teachers' on the basis of years of experience a second t-test was computed. The results are presented in table 5 .

Table 5. Differences in the levels of teachers' organizational commitment in the Islamic School by years of experience

\begin{tabular}{|l|l|c|c|c|c|}
\hline \multicolumn{1}{|c|}{ Variable } & \multicolumn{1}{|c|}{ Teacher's experience } & mean & $\begin{array}{c}\text { Std. } \\
\text { Deviation }\end{array}$ & t-value & Sig. \\
\hline \multirow{2}{*}{ Affective } & 5 years or less & 20.29 & 6.56 & -0.44 & 0.666 \\
\cline { 2 - 4 } & More than 5 years & 21.33 & 3.50 & & \\
\hline \multirow{2}{*}{ Continuance } & 5 years or less & 23.00 & 3.76 & 0.22 & 0.830 \\
\cline { 2 - 4 } & More than 5 years & 22.67 & 3.32 & & 0.647 \\
\cline { 1 - 4 } Normative & 5 years or less & 19.86 & 5.88 & -0.47 & 0.644 \\
\cline { 2 - 4 } $\begin{array}{l}\text { Overall } \\
\text { commitment }\end{array}$ & More than 5 years & 21.00 & 5.41 & & 0.759 \\
\cline { 2 - 4 } & More than 5 years & 63.14 & 15.56 & -0.31 & \\
\hline
\end{tabular}

$\mathrm{df}=21 \quad$ n. $(5$ years or less $)=14 \quad$ n. $($ more than 5 years $)=9$

The results of this t-test again display no impact of teachers' experience on the levels of organizational commitment. This is not consistent with the findings of Reyes (1992) that suggested teachers' years of experience correlate negatively with their organizational commitment but it does reinforce Lok and Crawford's (1999) finding that years of experience fail to show any relationship with commitment. Having said this, the 
reader is reminded that the small sample size may have prevented finding significant differences due to lack of statistical sensitivity.

\section{Teachers' Perceptions of the School Principal's Leadership Style}

As previously stated "the full range of leadership, as measured by the MLQ, implies that every leader displays a frequency of both the transactional and transformational factors, but each leader's profile involves more of one and less of the other" (Bass, 1999, p. 11). Thus, to investigate teachers' perceptions of the principal's prevailing leadership style, the means and standard deviations were computed according to teachers' responses on each factor of leadership on the MLQ (see table 6).

Table 6.Means and standard deviations of leadership styles according to teachers' responses on the MLQ.

\begin{tabular}{|l|c|c|}
\hline \multicolumn{1}{|c|}{ Style of Leadership } & mean & Std. deviation \\
\hline Transformational Leadership & 81.74 & 16.21 \\
\hline Transactional Leadership & 35.13 & 4.54 \\
\hline Laissez Faire (non-leadership) & 10.09 & 3.22 \\
\hline
\end{tabular}

The table shows that transformational leadership is the prevailing style in the Islamic School with a high score of "81.74" (range between 25 and 125). It is much higher than the scores of both transactional leadership "35.13" (range from 15 to 75) and laissez faire "10.09" (range from 5 to 25). This indicates that teachers in the Islamic School view their principal as a role model who demonstrates high moral standards and avoids the use of power either unnecessarily or for personal gain. They perceive coaching and mentoring as the leadership behaviours followed to help them go through their work. A teacher expressed her perception about the school's principal by saying that:

I know I am doing a good job so sometimes I need some praise just to keep going. My principal is capable of doing that; she is very professional and has much experience. She helps me a lot and I appreciate that.... I feel valued and I feel worthwhile because of her. However, as she is part- timer her time is much limited.

To have a more detailed understanding of the prevailing leadership style in the Islamic School, the means and standard deviations for the different leadership styles subscales are calculated and presented in table 7. 
Table 7. Means and standard deviations of leadership styles subscales according to teachers' responses on the $M L Q$

\begin{tabular}{|l|l|c|c|}
\hline \multicolumn{1}{|c|}{ Rank } & \multicolumn{1}{|c|}{ Leadership Subscales } & Mean & Std. Deviation \\
\hline 1 & Inspirational motivation & 18.26 & 3.95 \\
\hline 2 & Idealized attributes & 17.30 & 3.30 \\
\hline 3 & Intellectual stimulation & 17.26 & 3.08 \\
\hline 4 & Idealized behaviours & 17.04 & 3.94 \\
\hline 5 & Management-by-exception (active) & 12.09 & 2.45 \\
\hline 6 & Individual consideration & 11.87 & 4.41 \\
\hline 7 & Contingent reward & 11.83 & 3.41 \\
\hline 8 & Management-by-exception (passive) & 11.22 & 3.13 \\
\hline 9 & Laissez faire & 10.09 & 3.22 \\
\hline
\end{tabular}

From this table, it appears that the transformational leadership subscales are the most dominating factors of all three leadership styles. The leadership subscales are ranked according to the scores they had on the MLQ (range between 5 and 25 for each subscale). The highest of them all is inspirational motivation with a score of 18.26 , followed directly by idealized attributes 17.30 next to it intellectual stimulation with equally high score of 17.26, and then idealized behaviours 17.04. The lowest score of all transformational leadership style's subscales is individual consideration with a score of 11.87 which may indicate that though teachers perceive their administration as inspiring, motivating and setting good example, they may need more attention especially regarding the way of treating them as individuals with different considerations.

The transactional leadership subscales, management-by-exception (active), contingent reward, and management-by-exception (passive) are rated comparatively lower, with scores of $12.09,11.83$ and 11.22 respectively. Laissez faire (the nonleadership style) is ranked lowest by teachers at the school.

From these results, it is clear that the most prominent leadership factors identified by teachers in the school were the four transformational dimensions of (a) inspirational motivation, (b) idealized attributes, (c) intellectual stimulation, and (d) idealized behaviours. Other dimensions, particularly those related to transactional and laissez faire leadership approaches did not dominate the leadership style of the principal as perceived by the teachers.

\section{Differences in Teachers' Perceptions of the Prevailing Leadership Style by Gender and} Years of Experience

In the following analyses, differences between male and female teachers' perceptions of the prevailing leadership style are explored first, then differences in perceptions of prevailing leadership style according to years of experience are examined. In order to explore the differences in the perceptions of the prevailing leadership style between male and female teachers in the Islamic School, a t-test was conducted. The results are presented in table 8 . 
Table 8. Differences in teachers' perceptions of the prevailing leadership style in the Islamic School according to gender

\begin{tabular}{|c|c|c|c|c|c|}
\hline Variable & Gender & Mean & Std. Deviation & t-value & Sig. \\
\hline \multirow[t]{2}{*}{ Transformational Leadership style } & male & 93.57 & 12.18 & \multirow[t]{2}{*}{2.60} & \multirow[t]{2}{*}{0.017} \\
\hline & female & 76.56 & 15.24 & & \\
\hline \multirow[t]{2}{*}{ Transactional Leadership style } & male & 37.71 & 4.23 & \multirow[t]{2}{*}{1.91} & \multirow[t]{2}{*}{0.069} \\
\hline & female & 34.00 & 4.31 & & \\
\hline \multirow[t]{2}{*}{ Laissez faire (non leadership) style } & male & 10.29 & 3.09 & \multirow[t]{2}{*}{0.19} & \multirow[b]{2}{*}{0.850} \\
\hline & female & 10.00 & 3.37 & & \\
\hline
\end{tabular}

$$
\mathrm{df}=21 \quad \text { n. }(\text { male })=7 \quad \text { n. }(\text { female })=16
$$

The only significant difference between male and female teachers is in their perceptions of transformational leadership style $(p=.017, \alpha<.05)$, whereas there is a slight and not significant difference in the perceptions of both male and female teachers regarding the transactional leadership style. Also, there is no difference in teachers' perceptions regarding laissez faire (non-leadership) style, which means that they both agree in their perception about these two styles. With respect to the transformational leadership style, male teachers, whose mean score is 93.57, perceive the principal's leadership behaviours more transformational than female teachers, whose mean score is 76.56 .

To explore the differences in teachers' perceptions of the prevailing leadership style in the Islamic School according to their years of experience, a fourth t-test was conducted (see table 9).

Table 9. Differences in teachers' perceptions of prevailing leadership style in the Islamic School by years of experience

\begin{tabular}{|c|c|c|c|c|c|}
\hline Variable & Teacher's experience & mean & Std. Deviation & t-value & Sig. \\
\hline \multirow{2}{*}{$\begin{array}{l}\text { Transformational } \\
\text { Leadership style }\end{array}$} & 5 years or less & 77.50 & 14.87 & \multirow[t]{2}{*}{-1.62} & \multirow[t]{2}{*}{0.120} \\
\hline & More than 5 years & 88.33 & 16.82 & & \\
\hline \multirow{2}{*}{$\begin{array}{l}\text { Transactional } \\
\text { Leadership style }\end{array}$} & 5 years or less & 34.64 & 4.38 & \multirow[t]{2}{*}{-0.64} & \multirow[t]{2}{*}{0.533} \\
\hline & More than 5 years & 35.89 & 4.94 & & \\
\hline \multirow{2}{*}{$\begin{array}{l}\text { Laissez faire (non } \\
\text { leadership) style }\end{array}$} & 5 years or less & 10.36 & 3.43 & \multirow[t]{2}{*}{0.49} & \multirow[t]{2}{*}{0.637} \\
\hline & More than 5 years & 9.67 & 3.00 & & \\
\hline
\end{tabular}

$$
\mathrm{df}=21 \quad \mathrm{n} .(5 \text { years or less })=14 \quad \mathrm{n} .(\text { more than } 5 \text { years })=9
$$

No significant differences in perception of leadership style were found on the basis of years of teaching experience. Again, given the small sample size the study may not have been sufficiently sensitive to detect such differences or they may simply not exist. 
Relationship between the Perceived Leadership Style and Teachers' Levels of Organizational Commitment in the Islamic School

To examine the influence of leadership style on teachers' organizational commitment, the three styles (i.e., transformational, transactional, and laissez faire) were regressed against each component of organizational commitment (i.e., normative, affective, and continuance).

Firstly, to examine the relationship between affective commitment subscale as the dependent variable and the three leadership styles as the independent variables we used a backward stepwise regression. It showed that only laissez faire (non leadership) style was found to have significant negative relationship to teachers' affective commitment (see table 10).

Table 10. Regression of leadership styles on teachers' affective commitment

\begin{tabular}{|l|c|c|c|c|c|}
\hline \multicolumn{1}{|c|}{ Leadership style } & constant & beta & $\begin{array}{c}\text { Partial } \\
\text { correlation }\end{array}$ & F-value & Sig. \\
\hline Transactional leadership style & 24.967 & -0.101 & -0.112 & 1.912 & 0.162 \\
\hline Transformational leadership style & 20.652 & 0.197 & 0.172 & 2.720 & 0.090 \\
\hline Laissez faire style & 28.195 & 0.436 & -.436 & 4.926 & $0.038^{*}$ \\
\hline
\end{tabular}

* significant variables $(\alpha=.05$ level).

The previous table demonstrates that from all the three styles that were regressed against affective commitment, it was only the laissez faire (non leadership) style that was significantly, but negatively, related $\left(\hat{\mathrm{y}}=28.195+-0.436 \mathrm{x}_{3}\right)$. Both of transformational and transactional leadership styles were excluded as they are not significantly related.

This indicates that teachers in the Islamic School do not feel much attachment to their school when the leadership role of the school's principal is absent or not effective. They may be sensitively reactive to this type of leadership behaviour because the school's principal occupies the job only on a part-time basis; they might quickly recognize the principal's absence within the shortest delay in addressing their professional problems. One teacher reinforces this suggestion saying that:

This school is very big; it has more than thirty teachers. We all do our best to teach that large number of children. Our principal is very professional and exerts a lot of effort to help us with our work. However, I must say that [Pat's] (a pseudonym) time is much limited; [Pat] is responsible for the whole school, nevertheless [Pat] is a part-timer. I think it would be much better for us and for the school to have a full time principal; this will solve many problems we face and will make us more satisfied with our work....

Meanwhile, the teachers' emotional attachment to the school didn't seem to be strongly affected by either the transactional or transformational leadership styles. This may not be surprising as it was mentioned previously that most teachers in the Islamic School chose to stay because it primarily serves the cultural and religious needs for 
children of their own minority. This could somehow has its impact on their sense of attachment and involvement within the school work, especially as human beings pass moral judgments on their own urges and, to a large extent, moral commitments explain the decision taken and behaviours exhibited (Sergiovanni, 1992, p. 19). A teacher reinforces this suggestion saying that:

Really, we are terribly underpaid, terribly underfunded, nevertheless I feel very satisfied because I am teaching these children the Islamic manners; this job for me is everything. Besides, I take my strength from the support of parents and the good behaviour of students which is worth well....

Secondly, to examine the relationship between normative commitment subscale as the dependent variable and the three leadership styles (i.e., transformational, transactional and laissez faire) as the independent variables, we apply a backward stepwise regression. The results reinforced the strong impact of laissez faire (non leadership) style as it was the only leadership style that found to have a significantly negative relationship to teachers' normative commitment (see table 11).

Table 11. Regression of leadership styles on teachers' normative commitment

\begin{tabular}{|l|c|c|c|c|c|}
\hline \multicolumn{1}{|c|}{ Leadership style } & constant & beta & $\begin{array}{c}\text { Partial } \\
\text { correlation }\end{array}$ & F-value & Sig. \\
\hline Transactional leadership style & 25.898 & -0.052 & -0.162 & 2.769 & 0.070 \\
\hline Transformational leadership style & 23.296 & 0.162 & 0.150 & 2.720 & 0.090 \\
\hline Laissez faire style & 29.629 & -0.531 & -0.531 & 8.240 & $0.009^{*}$ \\
\hline
\end{tabular}

$*$ significant variables $(\alpha=.01$ level $)$.

It is displayed that laissez faire (non leadership) style had a strong and significant negative relationship to teachers' normative commitment in the Islamic School ( $\hat{y}=$ $\left.29.629-0.531 \mathrm{x}_{3}\right)$.

Given the fact that an employee with strong affective and normative commitment practices more obligation and attachment to the organization, it is expected that he or she will have a greater enthusiasm and motivation to work and be beneficent. At the same time he or she may feel less committed in the absence of the principal's leadership and when he or she finds some, especially administrative, obstacles in his way.

Also, to explore if there is a relationship between the leadership style of the school's principal and teachers' willingness to continue working in the school, we used a backward stepwise regression with a continuance commitment subscale as the dependent variable and the three leadership styles (i.e., transformational, transactional, and laissez faire) as the independent variables (see table 12). 
Table 12. Regression of leadership styles on teachers' continuance commitment

\begin{tabular}{|l|c|c|c|c|c|}
\hline \multicolumn{1}{|c|}{ Leadership style } & constant & beta & $\begin{array}{c}\text { Partial } \\
\text { correlation }\end{array}$ & F-value & Sig. \\
\hline Transactional leadership style & 32.853 & -0.067 & -0.076 & 1.931 & 0.159 \\
\hline Transformational leadership style & 31.977 & 0.162 & -0.144 & 3.018 & 0.072 \\
\hline Laissez faire style & 27.994 & -0.464 & -0.464 & 5.775 & $0.026^{*}$ \\
\hline
\end{tabular}

* significant variables $(\alpha=.05$ level).

Again, laissez faire (non-leadership) style had a strong and significant negative relationship to teachers' continuing commitment in the Islamic School, $(\hat{y}=27.994+$ $\left.0.464 \mathrm{x}_{3}\right)$.

Thus, from all the three styles that were regressed against the components of organizational commitment, it was only the laissez faire (non leadership) style which was significantly related. This can be clearly exhibited by regressing the three styles of leadership against teachers' overall organizational commitment (see Table 13).

Table 13. Regression of leadership styles on teachers' overall organizational commitment

\begin{tabular}{|l|c|c|c|c|c|}
\hline \multicolumn{1}{|c|}{ Leadership style } & constant & beta & $\begin{array}{c}\text { Partial } \\
\text { correlation }\end{array}$ & F-value & Sig. \\
\hline Transactional leadership style & 83.718 & -0.079 & -0.092 & 0.413 & 0.684 \\
\hline Transformational leadership style & 75.925 & 0.103 & 0.094 & 2.432 & 0.097 \\
\hline Laissez faire style & 85.818 & -0.511 & -0.511 & 7.432 & $0.013^{*}$ \\
\hline
\end{tabular}

* significant variables $(\alpha=.05$ level $)$.

The previous table shows that laissez faire is the principal's leadership style which has a significant negative influence on teachers' overall organizational commitment in the Islamic School $\left(\hat{\mathrm{y}}=85.82+-0.51 \mathrm{x}_{3}\right)$. Both the transformational and the transactional leadership styles were excluded as they are not significantly related to teachers' organizational commitment. One suggestion which can be made based on these results is that teachers' emotional attachment to the Islamic School and their inclinations to stay working for it do not primarily depend on the positive leadership manifestations of the part time principal; at the same time they are very much influenced by his or her negative leadership manifestations. 


\section{Conclusions and Recommendations}

From the overall results in this study, it seems that a high level of teachers' overall organizational commitment does exist in the Islamic School. It appeared more appropriate, as Meyer and Allen suggested, to consider the affective, continuance and normative manifestations as components rather than types of organizational commitment; each one of the three components was measured and all of them recorded high scores on the OCQ.

The t-test results showed no influence on teachers' years of experience, nor on their gender, in terms of their levels of organizational commitment. One possibility for this result is that the small sample size may not have been sufficiently sensitive to detect such differences. A second possible explanation is that such a relationship simply does not exist, especially if results were interpreted according to the attraction, selection and attrition theory (i.e., those who prefer to stay in this very school might have the same amount of enthusiasm and motivation as most of them, if not all, are aware of its mission especially as they share the same culture and religion). The lack of gender difference in these results supports Kacmar's et al. (1999) findings that gender is not a good predictor of any of the forms of organizational commitment.

In this study we also found an overall agreement among teachers working in the Islamic School that the most prominent leadership style of the school principal was transformational. Furthermore, it was clearly evident that transactional leadership traits and laissez faire (non-leadership style) traits were also evident in the principal's leadership approaches. This reinforces the idea that while one leadership style is predominant, leaders use a range of leadership approaches (e.g., transformational, transactional and laissez faire) at different times.

The t-test results also indicated a significant differentiation between male and female teachers in viewing the level of transformational leadership style while they both gave similar opinions regarding the other two leadership styles of the school's principal. The backward stepwise regressions indicated that laissez faire (non-leadership) style had a strong and significant negative relationship to all the manifestations of teachers' organizational commitment in the Islamic School. Meanwhile, both transformational and transactional leadership styles didn't seem to have any influential impact on teachers' organizational commitment. This suggests teachers are very sensitive, in a negative way, to leader's non-leadership behaviours.

On the basis of the leader's leadership style, the findings do not explain the high levels of organizational commitment which teachers at the Islamic School demonstrated with respect to the organization. It is possible that the special mission of the organization itself, its environmental and cultural contexts play a very important role in securing organizational commitment from teachers. The Islamic School was set up by a Muslim minority group in Canada for teaching their children the Islamic culture and Arabic language. This is done through an integration of Islamic curriculum and that which is prescribed by the state. The majority of teaching staff are Muslim, and so, it is not surprising that they be emotionally attached to the school and feel committed to its mission.

We recommend that future research replicate this work with a larger sample size, but more importantly, an exploration of mediating factors between organizational 
commitment and leadership style needs to be conducted. Once these have been identified, then, as a field, we will be in a better position to better understand the conception of leadership and it relationship to teachers' sense of organizational commitment.

\section{References}

Bass, B.M. (1999). Two decades of research and development in transformational leadership, European Journal of Work and Organizational Psychology, 8(1), 932.

Bass, B.M. \& Steidlmeier, P. (1999). Ethics, character, and authentic transformational leadership behaviour. Leadership Quarterly, 10(2), Electronic Version, p. 4 of 35. Available at http://web.ebscohost.com.login.ezproxy.library.ualberta.ca/ehost/delivery?vid=5 \&hid=9. Accessed on 12/22/2006

Bass, B.M. \& Bruce J. Avolio (1996). The Multifactor Leadership Questionnaire (MLQ). Available at http://www.mindgarden.com/products/mlqr.htm Accessed on 16/1/2007

Blase, J. \& Blase, J. (2003). Breaking the silence: Overcoming the problem of principal mistreatment of teachers. Thousand Oaks, CA: Corwin Press, Inc.

Begley, T.P. \& Zaretsky, L. (2004). Democratic school leadership in Canada's public school systems: Professional value and social ethic. Journal of Educational Administration, 42(6), 640-655.

Bennis, W. \& Nanus, B. (2003). Leaders: Strategies for taking charge. New York: Harper Business Essentials.

Bennis, W. \& Townsend, R. (2005). Reinventing leadership: Strategies to empower the organization. New York: Collins Business Essentials.

Bogler, R. (2001). The influence of leadership style on teacher job satisfaction. Educational Administration Quarterly, 37(5), 662-683.

Bottery, M. (2004).The challenges of educational leadership. London: Paul Chapman Publishing.

Burton, J.B., Lee, T.W. \& Holton, B.C. (2002). The influence of motivation to attend, ability to attend and organizational commitment on different types of absence behaviours. Journal of Managerial Issues, 14(2), 181-197.

Bush, T. (2003). Educational leadership and management: Scope and diversity. Educational Management and Administration, 31(4), 347-351.

Camilleri, E. (2006). Towards developing an organizational commitment - public service motivation model for the Maltese public service employees. Public Policy and Administration, 21(1), 63-83.

Chance, P.L. \& Chance, E.W. (2002). Introduction to educational leadership and organizational behaviour: Theory into practice. Larchmont, NY: Eye on Education.

Coladarci, T. (1992). Teachers' sense of efficacy and commitment to teaching. Journal of Experimental Education, 60(4), 323-337.

Drake, T. \& Roe, W.H. (2003). The principalship (6th Ed.). New Jersey: Merrill Prentice Hall. 
Early, P. (2003). Leaders or followers? Governing bodies and their role in leadership. Educational Management and Administration, 31(4), 353-367.

Foels, R., Driskell, J.E., Mullen, B., \& Salas, E. (2000). The effect of democratic leadership on group members' satisfaction; An integration. Small Group Research, 31(6), 676-701.

Fiore, D.J. (2004). Introduction to educational administration: Standards, theories, and practice. Larchmont, NY: Eye on Education.

Geijsel, F., Sleegers, P., Leithwood, K., Jantzi, D. (2003). Transformational leadership effects on teachers' commitment and effort toward school reform. Journal of Educational Administration, 41(3), 228-256.

Geurts, S.A. (1999). Absenteeism, turnover intention and inequity in the employment relationship. Work and Stress, 13(3), 253-267.

Hayes, D., Cristie, P., Mills, M. \& Lingard, B. (2004). Productive leaders and productive leadership: Schools as learning organizations. Journal of Educational Administration, 42 (6), 520-538.

House, R. \& Aditya, R.N. (1997). The social scientific study of leadership: Quo vadis? Journal of Management, 23(3), 409-473.

Jaros, S.J. (1997). An assessment of Meyer and Allen's (1991) three-component model of organizational commitment and turnover intentions. Journal of Vocational Behaviour, 51, 319-337.

Joffres, C.E. (1998). Beyond organizational commitment: Selected elementary school teachers' work commitments. Unpublished doctoral dissertation, University of Alberta, Edmonton, Canada.

Johansson, O. (2004). Democracy and leadership - or training for democratic leadership. Journal of Educational Administration, 42(6), 620 -624.

Jones, J. R. (1998). Organization and occupation influences in the attraction-selectionattrition process. Journal of Applied Psychology, (83) 6, 869-891.

Jung, D.I. \& Sosik, J.J. (2002). Transformational leadership in work groups; the role of empowerment, cohesiveness, and collective efficacy on perceived performance. Small Group Research, 33(3), 313-336.

Kacmar, K.M., Carlson, D.S., \& Brymer, R.A. (1999). Antecedents and consequences of organizational commitment: A comparison of two scales. Educational and Psychological Measurement, 59(6), 976-994.

Kanungo, R.N. \& Conger, J.A. (1992). Charisma: Exploring New Dimensions of Leadership Behaviour, Psychology and Developing Societies, 4(1), 21-37.

Katerynych, D.A. (1994). Teacher commitment. Unpublished Master Thesis, University of Alberta, Edmonton, Canada).

Ladkin, D. (2006). The enchantment of charismatic leader: Charisma reconsidered as aesthetic encounter. Leadership, 2(2), 165-179.

Lambert, L. (2002). A framework for shared leadership. Educational Leadership, 59(8), $37-40$.

Lok, P. \& Crawford, J. (1999). The relationship between commitment and organizational culture, subculture, leadership style and job satisfaction in organizational change and development. Leadership and Organizational Development Journal, 20(7), 365-373. 
Marks, H.M. \& Printy, S.M. (2003). Principal leadership and school performance: An integration of transformational and instructional leadership. Educational Administration Quarterly, 39(3), 370-397.

Meyer, J.P. \& Allen, N.J. (2004). TCM Employee Commitment Survey (revised version 1993) - Academic Package, University of Western Ontario. Available at http://www.employeecommitmentresearch.com Accessed on16/1/2007

Meyer, J.P. \& Allen, N.J. (1997). Commitment in the workplace. London: Sage Publications.

Meyer, J.P. \& Allen, N.J. (1991). A three-component conceptualization of organizational commitment. Human Resource Management Review, 1(1), 61-89.

Meyer, J.P. \& Heroscvitch, L. (2001). Commitment in the workplace: A general model. Human Resource Management Review, 11, 299-326.

Meyer, J.P. \& Smith, C.A. (2000). HRM practices and organizational commitment: Test of mediation model. Canadian Journal of Administrative Science, 17(4)319-331.

Meyer, J.P., Stanley, D.J., Heroscvitch, L., \& Topolnytsky, L. (2002). Affective, continuance, and normative commitment to the organization: A meta-analysis of antecedents, correlates, and consequences. Journal of Vocational Behaviour, 61, 20-52.

Phillips, S., Raham, H. \& Renihan, P. (2003). The Role of The School Principal: Status and Future Challenges in Managing Effective Schools, A report submitted to the Ontario Ministry of Education by The Society for The Advancement of Excellence in Education. Toronto: Queen's Printer for Ontario.

Powell, D.M. \& Meyer, J.P. (2004). Side-bet theory and the three-component model of organizational commitment. Journal of Vocational Behaviour, 65, 157-177.

Prestine, N.A. \& Nelson, B.S. (2005). How can educational leadership support and promote teaching and learning? New conceptions of learning and leading in schools. In Firestone, William A. \& Riehl, C. (Eds.), A New Agenda for Research in Educational Leadership (pp. 46-60). New York: Teachers College Press.

Reinhartz, J. \& Beach, D.M. (2004). Educational leadership: Changing schools, changing roles. Boston: Pearson Education, Inc.

Reyes, P. (1992). Preliminary models of teacher organizational commitment: Implications for restructuring the work place. Madison, WI: Center on Organization and Restructuring of Schools.

Sergiovanni, T.J. (1992). Moral leadership, getting to the heart of school improvement. San Francisco: Jossey-Bass Publishers.

Shah, S. (2006). Educational leadership: an Islamic Perspective, British Educational Research Journal, 32(3), 363-385.

Shen, J. (2005). School principals. New York: Peter Lang Publishing, Inc.

Steyrer, J. (1998). Charisma and the archetype of leadership. Organization Studies, 19(5), 807-828.

Thomas, D.M. \& Davis, E.E. (2000). Legal and ethical bases for educational leadership. In Bogue, E.G. et al (Eds.) Readings on Leadership in Education, from The Archives of Phi Delta Kappa International. Bloomington, IN: Phi Delta Kappa Educational Foundation.

Turner, S. (2003). Charisma reconsidered. Journal of Classical Sociology, 3(1), 5-26. 
Yoon, J. \& Thye, S. (2002). A dual process model of organizational commitment, job satisfaction and organizational support. Work and Occupations, 29(1), 97-124.

Yu, H., Leithwood, K., \& Jantzi, D. (2002). The effects of transformational leadership on teachers' commitment to change in Hong Kong. Journal of Educational Administration, 40(4/5), 368-389.

Yukl, G. (1999). An evaluation of conceptual weaknesses in transformational and charismatic leadership theories. Leadership Quarterly, 10(2), Electronic Version, p. 2 of 20 . Available at http://web.ebscohost.com.login.ezproxy.library.ualberta.ca/ehost/delivery?vid=5 \&hid $=11 \ldots$ Accessed on 22/12/2006

Zeffane, R. (1994). Patterns of organizational commitment and perceived management style: A comparison of public and private sector employees. Human Relations, 47(8), 977-1010. 